\title{
Studi Kelimpahan Dan Keanekaragaman Kepiting Di Hutan Mangrove Dan Padang Lamun Di Pantai Mertasari
}

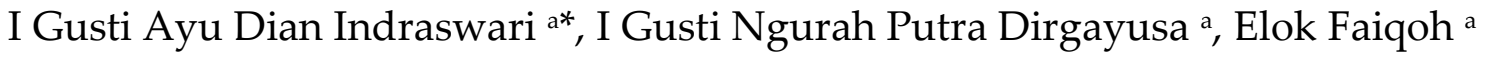 \\ aProgram Studi Ilmu Kelautan, Fakultas Kelautan dan Perikanan, Universitas Udayana, Kampus UNUD Bukit Jimbaran, Bali 80361, Indonesia \\ **Penulis koresponden. Tel.: +62-857-382-661-93 \\ Alamat e-mail: ayudianswarry@yahoo.com
}

Diterima (received) 20 Juni 2017; disetujui (accepted) 19 September 2017; tersedia secara online (available online) 25 September 2017

\begin{abstract}
The ecosystem of mangroves and seagrass in Mertasari Beach are located nearby and and inhabited with various species that coexist, One of the association's creature in mangrove ecosystem and seagrass ecosystem is crab. There were a habitat selection of crabs, so it does possible to find the same species in the mangrove ecosystem and seagrass ecosystem. This research aims to know the type, abundance and diversity of crabs in the Mertasari Beach on two different ecosystems such as mangrove and seagrass ecosystem. The research were conducted in January until February 2017. In this research the Random sampling method was used to create a $1 \times 1 \mathrm{~m} 2$ square placed on 5 substations at each research station. Crab sampling was conducted at the lowest tide and has been done twice in a month. The results showed there were 7 families with 20 species. In both ecosystem were found 3 spesies such as Scylla serrata, Grapsus albolineatus and Myomenippe fornasinii. This happens because of several factors, like the tidal and the flow of the river into habitat removal by crabs. The highest abundance of crabs was found in mangrove stations of 411 individuals $/ \mathrm{m}^{2}$, while at the seagrass station were 93 individuals $/ \mathrm{m}^{2}$ due to food availability and environmental conditions. The highest value diversity index $(\mathrm{H})$ at mangrove station was 1.94 and seagrass station of 1.73 with moderate category indicated in those area had sufficient productivity, conditions of the ecosystem is pretty balanced and moderate ecological pressure.
\end{abstract}

Keywords:Crabs; Mangrove; Seagrass

\begin{abstract}
Abstrak
Ekosistem mangrove dan padang lamun di Pantai Mertasari letaknya berdekatan dan dihuni berbagai macam biota yang hidup berdampingan, dimana salah satu biota asosiasi pada ekosistem mangrove dan padang lamun adalah kepiting. Terdapat adanya pemilihan habitat dari kepiting, sehingga tidak menutup kemungkinan akan ditemukan jenis yang sama di ekosistem mangrove dan ekosistem padang lamun. Penelitian ini bertujuan untuk mengetahui jenis, kelimpahan dan keanekaragaman kepiting di Pantai Mertasari pada dua ekosistem yang berbeda yakni, ekosistem mangrove dan padang lamun. Pengamatan dilakukan pada bulan Januari-Februari 2017. Pada pengamatan in digunakan metode Random sampling dengan membuat kwadrat $1 \times 1 \mathrm{~m}^{2}$ yang di letakkan pada 5 substasiun pada masing-masing stasiun pengamatan.Pengambilan sampel kepiting dilakukan pada surut terendah dan dilakukan sebanyak dua kali dalam sebulan. Hasil penelitian menunjukkan terdapat 7 famili dengan 20 spesies. Dimana pada kedua ekosistem tersebut ditemukan 3 spesies yang sama yakni Scylla serrata, Grapsus albolineatus dan Myomenippe fornasinii. Hal ini terjadi karena beberapa faktor, salah satunya pasang surut serta adanya aliran sungai yang menjadi media pemindahan habitat dari kepiting tersebut. Kelimpahan kepiting tertinggi terdapat pada stasiun mangrove sebesar 411 individu/ $\mathrm{m}^{2}$ sedangkan pada stasiun lamun sebesar 93 individu/ $\mathrm{m}^{2}$ yang disebabkan factor ketersediaan makanan dan kondisi lingkungan. Nilai Indeks Keanekaragaman $\left(\mathrm{H}^{\prime}\right)$ tertinggi pada stasiun mangrove sebesar 1.94 dan stasiun lamun sebesar 1.73 dengan kategori sedang.
\end{abstract}

Kata Kunci:Kepiting; Mangrove; Lamun

\section{Pendahuluan}

Kawasan ekosistem pantai yang mempunyai berbagai sumber daya alam berpotensi untuk dikembangkan. Ekosistem pantai terdiri atas komponen makhluk hidup (biotik) dan komponen makhluk tak hidup (abiotik). Salah satu potensi penting yakni meliputi ekosistem mangrove, 
padang lamun dan terumbu karang. Ketiga ekosistem tersebut mempunyai fungsi secara ekologis yang berkesinambungan dan mendukung satu sama lain. Fungsi ekologisnya yaitu tempat mencari makan (feeding ground), daerah asuhan (nursery ground), tempat pemijahan (spawning ground) bagi berbagai macam spesies ikan karang, gastropoda, bivalvia, dan crustacean serta memiliki peranan positif sebagai penyeimbang faktor biologis, fisik dan kimia (Effendy, 2009).

Ekosistem mangrove dan padang lamun di Pantai Mertasari letaknya berdekatan dan dihuni berbagai macam biota yang hidup berdampingan, dimana salah satu biota asosiasi pada ekosistem mangrove dan padang lamun adalah kepiting. Kepiting memiliki peran dalam mineralisasi, mengubah balik bahan organik dalam perairan, membantu siklus karbon, meningkatkan distribusi oksigen di dalam tanah dan menjadi penyedia makan alami bagi berbagai jenis biota (Prianto, 2007). Masing-masing jenis kepiting memiliki habitat daerah kesukaan yang berbeda (Epifanio, 2013). Dari pemilihan tempat tinggal yang berbeda berdasarkan daerah kesukaannya tersebut maka tidak menutup kemungkinan akan ditemukan jenis yang sama di ekosistem mangrove dan ekosistem padang lamun.

Pantai mertasari merupakan salah satu pantai yang ramai dikunjungi wisatawan baik lokal maupun mancanegara. Terdapat berbagai aktivitas yang dapat dilakukan seperti menikmati pemandangan matahari terbenam, mandi, bermain kano, memancing dan telah disediakan fasilitas penunjang seperti restoran, villa dan hotel yang menghadap langsung ke arah laut. Adanya pembangunan pelabuhan dan aktivitas jalur lalu lintas kapal pada kawasan tersebut. Perubahan yang terjadi disana dapat menyebabkan ekosistem yang ada (mangrove dan lamun) menjadi tidak stabil, sehingga kemudian seluruh aktivitas dari ekosistem menjadi terganggu. Seperti biota kepiting yang hidup di kedua ekosistem tersebut akan terkena dampak secara langsung sehingga terdapat ancaman pada populasi kepiting tersebut. Sehingga dilakukan penelitian Studi Kelimpahan Dan Keanekaragaman Kepiting Di Hutan Mangrove dan Padang Lamun Di Pantai Mertasari, dikarenakan di daerah Bali masih belum dilakukan mengenai penelitian terkait mengenai kepiting pada dua ekosisem yang berbeda. Hasil dari penelitian ini dapat mengidentifikasi jenis, kelimpahan serta keanekaragaman kepiting yang ditemukan pada dua ekosistem yang berbeda di kawasan Pantai Mertasari.

\section{Metode Penelitian}

\subsection{Waktu dan Tempat}

Lokasi penelitian ini adalah daerah ekosistem mangrove dan ekosistem padang lamun di Pantai Mertasari, Denpasar, Bali. Pantai Mertasari yang berada pada koordinat Latitude : $8^{\circ} 42^{\prime} 44^{\prime \prime} \mathrm{S}$ dan Longitude : $115^{\circ} 15^{\prime} 4^{\prime \prime}$ E. Lokasi ini dipilih sebagai tempat berlangsungnya sampling karena pada

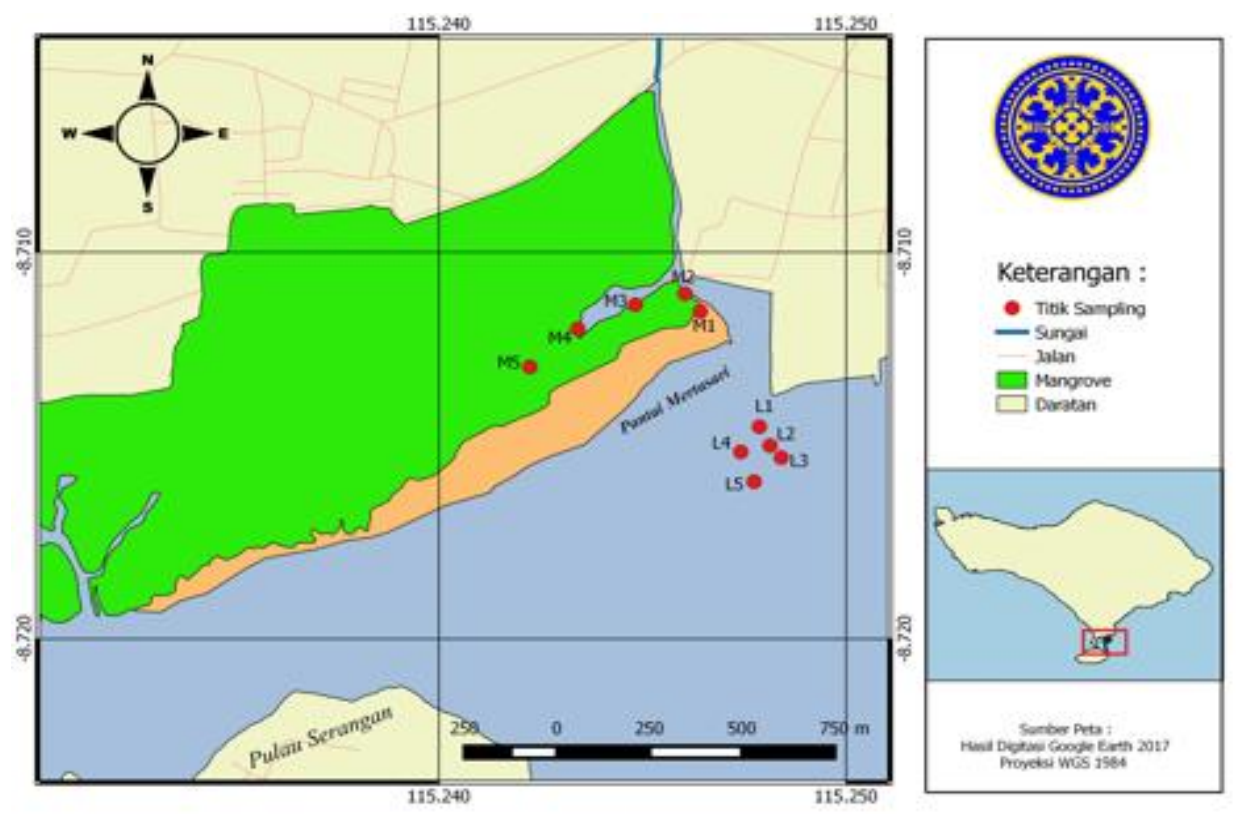

Gambar 2. Lokasi studi 
kawasan Pantai Mertasari memiliki dua ekosistem yang hidup berdampingan yakni ekosistem hutan mangrove dan ekosistem padang lamun. Waktu penelitian ini dilakukan pada bulan Januari sampai Februari 2017.

\subsection{Alat dan Bahan}

Alat dan bahan merupakan sarana yang diperlukan untuk menunjang pengambilan data maupun sampel. Adapun alat dan bahan yang digunakan untuk penelitian ini dapat dilihat pada table berikut:

Tabel 1

Bahan dan Alat Penelitian

\begin{tabular}{|c|c|c|c|}
\hline Jenis & Keterangan & Satuan & Kegunaan \\
\hline Bahan & $\begin{array}{l}\text { Ikan } \\
\text { Formalin 10\% }\end{array}$ & & $\begin{array}{l}\text { Umpan kepiting } \\
\text { Mengawetkan sampel } \\
\text { biota }\end{array}$ \\
\hline \multirow[t]{11}{*}{ Alat } & Alat tulis & - & Mencatat data \\
\hline & $\begin{array}{l}\text { Buku } \\
\text { Identifikasi } \\
\text { Kepiting }\end{array}$ & - & $\begin{array}{l}\text { Mengidentifikasi jenis } \\
\text { kepiting }\end{array}$ \\
\hline & Transek $(1 \times 1)$ & $\mathrm{m}^{2}$ & $\begin{array}{l}\text { Menentukan batasan } \\
\text { sampel yang akan } \\
\text { diambil dan } \\
\text { Menghitung } \\
\text { kelimpahan specimen }\end{array}$ \\
\hline & Ember & - & $\begin{array}{l}\text { Menampung sampel } \\
\text { biota }\end{array}$ \\
\hline & Topless & - & $\begin{array}{l}\text { Menyimpan sampel } \\
\text { biota }\end{array}$ \\
\hline & Tissu & - & Membersihkan alat \\
\hline & Kertas label & - & Menandai sampel \\
\hline & $\begin{array}{l}\text { GPS (Global } \\
\text { Possitioning } \\
\text { System) }\end{array}$ & - & $\begin{array}{l}\text { Menentukan titik } \\
\text { kooerdinat lokasi }\end{array}$ \\
\hline & Sekop & - & $\begin{array}{l}\text { Menggali lubang } \\
\text { untuk mengambil } \\
\text { kepiting }\end{array}$ \\
\hline & Thermometer & ${ }^{\circ} \mathrm{C}$ & Mengukur suhu \\
\hline & Kamera & - & $\begin{array}{l}\text { Mendokumentasikan } \\
\text { penelitian }\end{array}$ \\
\hline
\end{tabular}

\subsection{Penentuan Stasiun Penelitian}

Terdapat 2 stasiun pengamatan yang diambil yakni dihutan mangrove dan padang lamun. Masing-masing stasiun dibagi menjadi 5 substasiun. Pengambilan sampel dilakukan sebanyak dua kali dalam sebulan. Sementara itu, sub-stasiun ditentukan berdasarkan metode random sampling. Metode random sampling merupakan suatu proses pengambilan sampel yang dilakukan dengan memeberikan kesempatan yang sama pada setiap sampel populasi untuk menjadi anggota sampel (Zulkifli dan Setiawan, 2011).

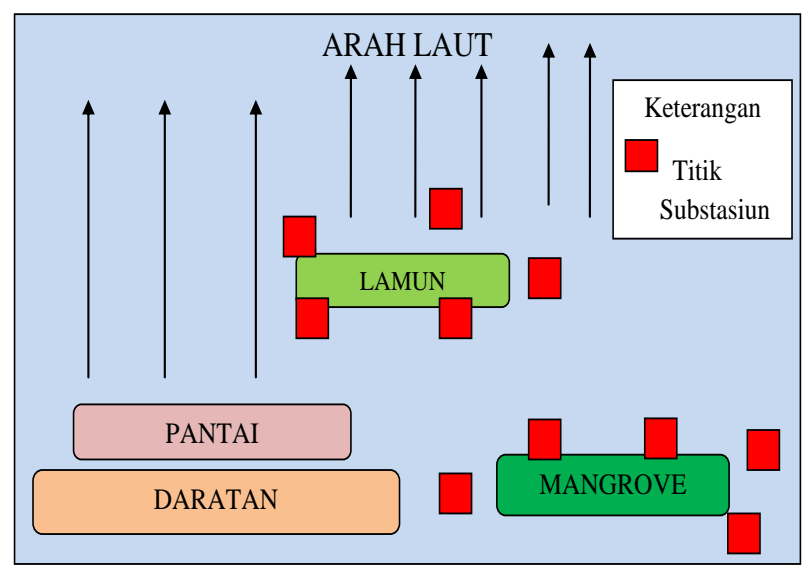

Gambar 2. Titik stasiun dan substasiun pengambilan data

\subsection{Pengambilan Data Kepiting}

Perhitungan kelimpahan kepiting dilakukan dengan membagi jumlah individu kepiting dengan satuan luas daerah pengambilan sampel. Sampling kepiting yang dilakukan adalah dengan menggunakan trasnsek yang memiliki satuan luas meter $(\mathrm{m})$, yaitu dengan ukuran $1 \mathrm{~m} \times 1 \mathrm{~m}$ atau dengan luas $1 \mathrm{~m}^{2}$.

Pengambilan contoh untuk kepiting dilakukan pada surut terendah. Lokasi untuk pengambilan sampel didasarkan pada ketersediaan vegetasi mangrove dan padang lamun yang mewakili wilayah penelitian. Pengambilan data sampel kepiting dilakukan dengan menggunakan transek dan perangkap rangka besi. Transek kuadrat yang digunakan memiliki ukuran $1 \times 1 \mathrm{~m}^{2}$, terbuat dari pipa paralon dan Perangkap rangka besi memiliki ukuran 100x100 cm, terbuat dari rangka besi dengan dilapisi jaring dari kawat. Pengambilan sampel kepiting dapat dilakukan dengan mengambil kepiting yang ada di permukaan substrat dengan tangan dan untuk kepiting yang ada di bawah substrat atau didalam lubang diambil dengan menggali substrat dengan menggunakan sekop sedalam kurang lebih $15 \mathrm{~cm}$. Semua kepiting yang tercuplik di dalam transek diambil kemudian ditaruh dalam ember. Sampel yang telah didapatkan dicuci dengan air mengalir untuk menghilangkan bekas sedimen yang melekat pada sampel biota. Setelah itu sampel 
dimasukkan kedalam lemari es selama 30 menit, lalu diawetkan dengan formalin $10 \%$. Selanjutnya sampel tersebut disimpan dalam topless dan diberikan label. Sampel di identifikasi dengan menggunakan buku identifikasi kepiting menurut (Ng et al., 2008; Pratiwi dan Widyastuti, 2013) di Laboratorium Ilmu Kelautan, Fakultas Kelautan dan Perikanan, Universitas Udayana.

\subsection{Parameter Lingkungan}

Pengukuran parameter lingkungan dilakukan untuk mengetahui kondisi lingkungan yang mempengaruhi kepiting pada habitatnya. Parameter suhu, salinitas dan substrat diambil satu kali pada masing-masing stasiun pengamatan. Pengukuran parameter suhu pada substrat langsung diujji dilapangan, sedangkan parameter salinitas dan tekstur tanah dilakukan secara ex situ. Contoh substrat diambil secukupnya dan dimasukkan ke dalam kantong plastik berlabel untuk selanjutnya dibawa ke Laboratorium Ilmu Tanah, Fakultas Pertanian, Universitas Udayana dianalisis untuk melihat fraksi pasir, debu dan liat. Analisis mekanis tanah menghasilkan pemisahan tanah menjadi bagian-bagian pasir, liat dan lempung (Harahap, 2014). Dengan menggunakan metode segitiga Millar, tipe substrat di lokasi pengamatan dapat ditentukan berdasarkan kandungan teksturnya.

\subsection{Analisis Data}

\subsubsection{Kelimpahan Kepiting}

Kelimpahan adalah jumlah individu per satuan luas atau per satuan volume. Kelimpahan kepiting dapat dihitung dengan menggunakan persamaan 1 :

$$
\begin{aligned}
& N=\frac{\sum n i}{A} \\
& \mathrm{~N} \quad=\text { Kelimpahan kepiting bakau (ind/ m2) } \\
& \sum \mathrm{ni} \quad=\text { Jumlah individu jenis ke-I (ind) } \\
& \mathrm{A} \quad=\text { Luas kotak pengambilan sampel (m2) }
\end{aligned}
$$

\subsubsection{Indeks Keanekaragaman $\left(\mathrm{H}^{\prime}\right)$}

Indeks keanekaragaman digunakan untuk mengetahui tingkat keanekaragaman jenis. Persamaan yang digunakan untuk menghitung indeks ini adalah persamaan Shanon-Wiener (Krebs, 2016).

$$
\begin{array}{ll}
H^{\prime}= & -\sum_{i=1}^{S}(p i) \ln (p i) \\
\mathrm{H}^{\prime} & =\text { indeks keanekaragaman Shannon-Wiener } \\
\mathrm{S} \quad= & \text { Jumlah spesies } \\
\mathrm{pi} \quad=\text { proporsi jumlah individu jenis ke-I dengan } \\
\quad \text { jumlah individu total } \\
\mathrm{pi} \quad=\text { ni/N } \\
\mathrm{ni} \quad=\text { jumlah individu jenis ke-i } \\
\mathrm{N} \quad=\text { jumlah individu semua jenis }
\end{array}
$$

\section{Tabel 2}

Nilai Tolak Ukur Indeks Keanekaragaman (Hamidy, 2010).

\begin{tabular}{cl}
\hline $\begin{array}{c}\text { Nilai Tolak } \\
\text { Ukur }\end{array}$ & \multicolumn{1}{c}{ Keterangan } \\
\hline $\mathrm{H}^{\prime}<1,0$ & $\begin{array}{l}\text { Keanekaragaman rendah, miskin, } \\
\text { produktivitas sangat rendah sebagai } \\
\text { indikasi adanya tekanan yagn berat } \\
\text { dan ekosistem tidak stabil }\end{array}$ \\
$1,0<\mathrm{H}^{\prime}<$ & $\begin{array}{l}\text { Keanekaragaman sedang, } \\
\text { produktivitas cukup, kondisi } \\
3,322\end{array}$ \\
& $\begin{array}{l}\text { ekosistem cukup seimbang, tekanan } \\
\text { ekologis sedang }\end{array}$ \\
& $\begin{array}{l}\text { Keanekaragaman tinggi, stabilitas } \\
\text { ekosistem mantap, produktivitas } \\
\mathrm{H}^{\prime}>3,322\end{array}$ \\
& $\begin{array}{l}\text { tinggi, tahan terhadap tekanan } \\
\text { ekologis }\end{array}$ \\
\hline
\end{tabular}

\section{Hasil dan Pembahasan}

\subsection{Kesamaan Spesies Pada Ekosistem Mangrove dan} Lamun

Hasil komposisi jenis kepiting pada setiap stasiun hutan mangrove dan padang lamun di Pantai Mertasari ditemukan 20 spesies kepiting, yang 3 diantaranya dapat hidup pada ekosistem mangrove dan padang lamun, yaitu Scylla serrata (Portunidae), Grapsus albolineatus (Grapsididae), dan Myomenippe fornasinii (Menippidae) (Gambar 3). Ketiga spesies tersebut berasal dari family yang berbeda. Hal tersebut diduga diakibatkan oleh faktor pasang surut serta adanya aliran sungai atau daerah estuary dari wilayah hutan mangrove menuju kawasan padang lamun sehingga dengan adanya pasang surut membantu pemidahan 
habitat dari kepiting baik dari mangrove ke lamun ataupun sebaliknya.

Adanya kesamaan jenis pada kedua ekosistem tersebut meandakan bahwa terdapat keterkaitan pada eosistem mangrove dan lamun, Hal tersebut dibuktikan dengan ditemukannya spesies kepiting yang sama pada ekosistem mangrove dan ekosistem lamun, dimana kepiting betina yang beruaya ke laut untuk memijah di ekosistem padang lamun dan kepiting muda yang menuju ekosistem hutan mangrove untuk mencari makan dan berlindung. Keterkaitan antara ekosistem mangrove dan padang lamun menunjukkan hubungan timbal balik antar ekosistem sehingga jika salah satu dari ekosistem dimana kepiting ditemukan hilang atau rusak maka kepiting secara tidak langsung terganggu dan dapat menyebabkan kepiting terancam punah. Sehingga perlu dilakukannya konservasi pada ekosistem mangrove dan ekositem lamun untuk menjaga kelimpahan dan keanekaragaman organisme tersebut.

Kepiting menyukai kedalaman air dimana saat air surut masih terdapat air yang menggenang, sehingga memungkinkan kepiting untuk berpindah tempat, adanya factor pasang surut juga membantu kepiting dalam aktivitasnya dalam lubang galian, dimana lubang tersebut dapat dijadikan sebagai tempat tinggal dan memberikan perlindungan (Pratiwi, 2010). Keadaan habitat yang berubah-ubah dapat berpengaruh terhadap kemerataan jenis yang hidup pada habitat tersebut.

White and Madsen (2016) menyatakan bahwa distribusi dan zonasi kepiting didasarkan pada substrat, pasang surut dan factor makanan. Hal ini berkaitan dengan zonasi kepiting family grapsididae dan family portunidae yang umumnya dominan pada substrat berpasir serta berlumpur. Kawasan padang lamun dan hutan mangrove di Pantai Mertasari yang memiliki karakteristik substrat berpasir mendukung kehidupan kepiting. Hal serupa didukung oleh Prianto (2007) yang mengungkapkan bahwa substrat di sekitar hutan mangrove sangat mendukung kehidupan kepiting, terutama untuk melangsungkan perkawinan dan melakukan pergantian kulit disekitar perairan padang lamun. Perbedaan ekosistem mangrove dan padang lamun dapat mendukung kehidupan kepiting karena menjamin ketersediaan sumber makanan yang diperoleh dari serasah mangrove maupun lamun, banyak serasah dan bahan organik mendukung kehidupan berbagai organisme, seperti gastropoda dan bivalvia. Gastropoda dan bivalvia merupakan salah satu makanan alami kepiting (Toscano and Griffen, 2012; Moody and Aronson, 2012). Kondisi kepiting yang tidak menentu memungkinkan kepiting sering berpindah-pindah tempat dari segi mencari makanan maupun factor abiotik, hal ini terjadi sebagai akibat dari adanya perbedaan respon terhadap habitat secara lokal.

\subsection{Komposisi Jenis}

\subsubsection{Ekosistem Padang Lamun}

Komposisi spesies kepiting yang ditemukan pada

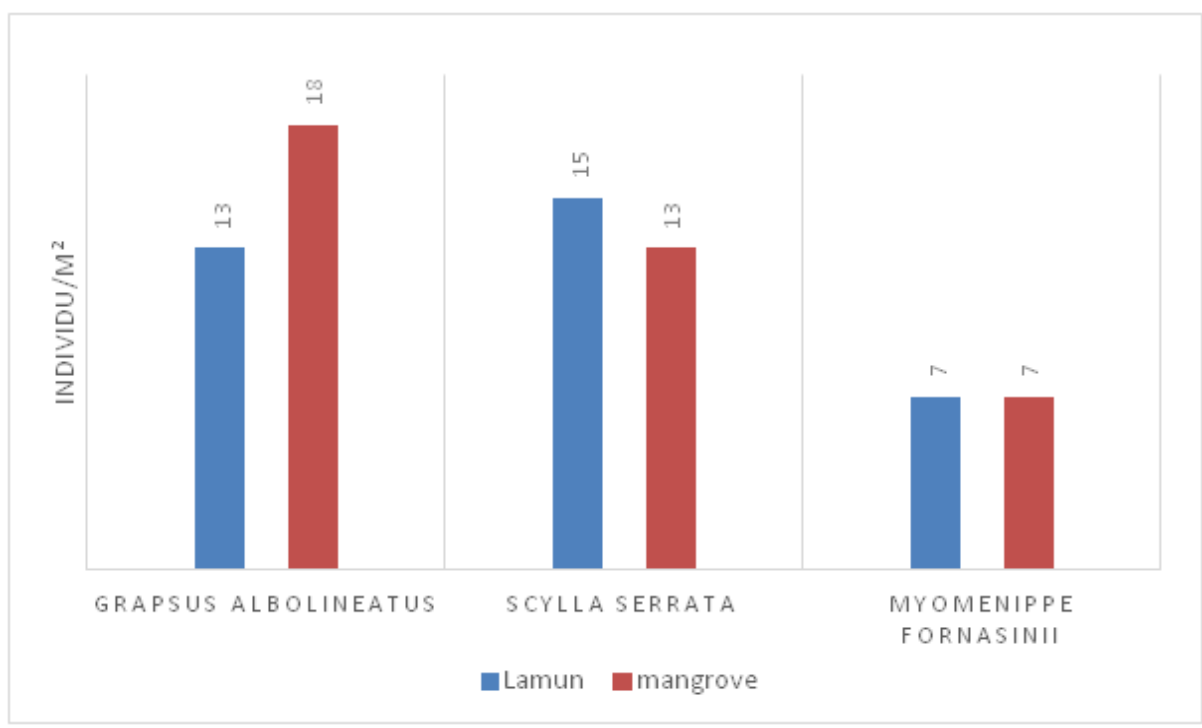

Gambar 3. Grafik Kesamaan Jenis Kepiting pada Stasiun Lamun dan Mangrove Pantai Mertasari 
penelitian ini, disajikan pada Gambar 4. Kepiting yang ditemukan di stasiun padang lamun Pantai Mertasari terdiri dari sembilan spesies yang termasuk kedalam lima family (Gambar 4), yaitu Clibanarius longitarsus, Clibanarius englaucus, Clibanarius eurysternus, dan Clibanarius striolatus (Diogenidae), Scylla serrata dan Scylla tanquberra (Portunidae), Grapsus albolineatus (Grapsididae), Matuta lunaris (Matutidae), Myomenippe fornasinii (Menippidae).

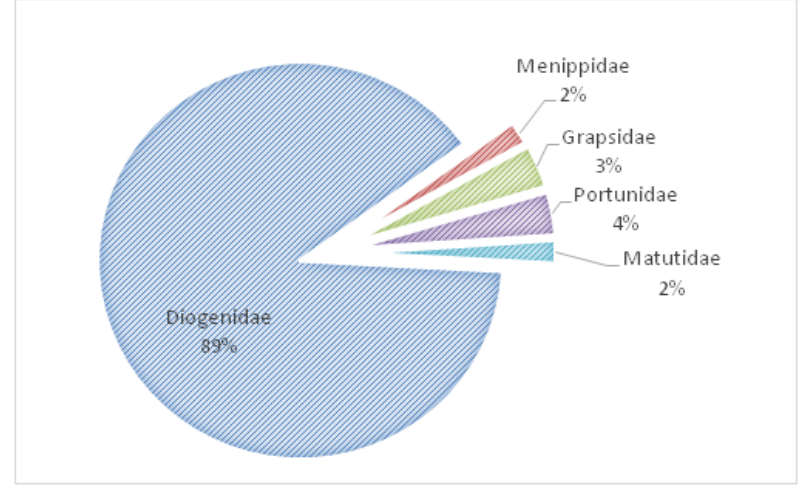

Gambar 4.Grafik Komposisi Jenis Kepiting di Padang Lamun

Spesies kepiting yang paling sering ditemukan adalah family Diogenidae, sedangkan yang jarang ditemukan adalah family Matutidae dan Menippidae (Gambar 4). Famili Diogenidae memiliki komposisi jenis sebesar $89 \%$ di stasiun padang lamun diduga karena spesies dari kelompok Anomura (hermit crab) atau kelomang ini memakan epifit algae yang menempel pada daun lamun, sehingga spesies ini mudah ditemukan pada substrat permukaan pada vegetasi padang lamun. Kepiting jenis ini merupakan pemakan segala (omnivore) dengan kecenderungan kearah pemakan daging (karnivora). Clibanarius sp. banyak ditemukan melekat pada daun dan akar lamun atau pantai berpasir yang banyak ditumbuhi lamun (Negri et al., 2012). Family Matutidae dan Menippidae memiliki komposisi jenis sebesar $2 \%$ pada stasiun padang lamun. Family Menippidae tersebar pada perairan dangkal pada daerah intertidal, pada substrat pasir berlumpur dan biasa ditemukan dibawah batu sedangkan family matutidae merupakan kepiting perenang bebas yang cepat dan kepiting jenis ini memiliki kemampuan dalam kamuflase di substrat pasir pada padang lamun (Ng and Davie, 2008), sehingga jarang ditemukan serta sulit untuk ditangkap.

\subsubsection{Ekosistem Hutan Mangrove}

Komposisi spesies kepiting yang ditemukan pada penelitian ini, disajikan pada (Gambar 5). Jenis kepiting yang ditemukan di Pantai Mertasari pada stasiun hutan mangrove terdiri dari lima family yang terbagi dalam 11 spesies (Gambar 10), yakni Uca perplexa, Uca forcipata, Uca rosea, Uca dussumieri, Uca triangularis, Uca jocelynae, dan Ocypode stimpsoni (Ocypodidae), Parasesarma rutilimanum (Sesarmidae), Scylla serrata (Portunidae), Grapsus albolineatus (Grapsidae), dan Myomenippe fornasinii (Menippidae). Spesies kepiting yang paling sering ditemukan adalah family Ocypodidae sedangkan yang jarang ditemukan adalah family Menippidae.

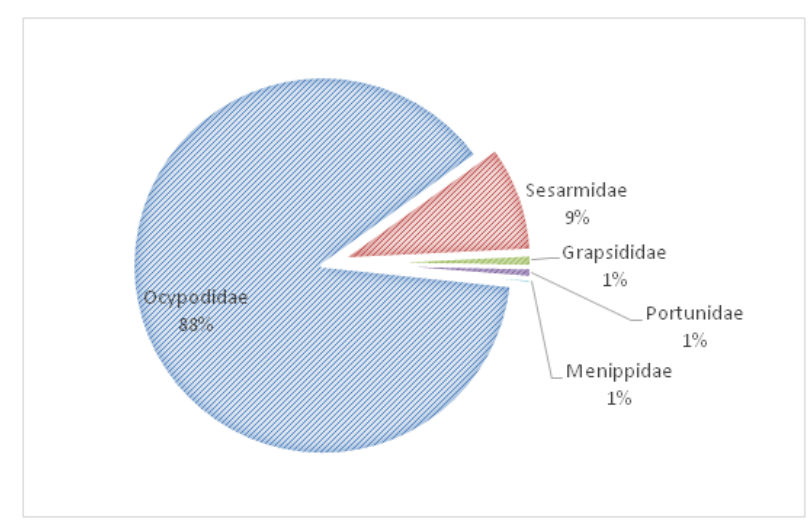

Gambar 5. Grafik Komposisi Jenis Kepiting di Hutan Mangrove

Spesies Uca $s p$ yang menjadi anggota family Ocypodidae merupakan jenis kepiting yang hidup dalam liang dengan pasang surut rendah dan banyak ditemukan (dominan) di hutan mangrove (Suprayogi, 2014). Hal ini disebabkan karena habitat yang ditempati sesuai dengan cara hidup dari jenis kepiting tersebut serta menunjangnya ketersediaan makanan berupa serasah daun mangrove, sehingga jenis kepiting ini paling dominan ditemukan hingga mencapai $88 \%$. Spesies Uca sp menggali lubang dan tinggal di dalam lubang untuk melindungi tubuhnya terhadap suhu yang tinggi, karena air yang berada dalam lubang galian dapat membantu mengatur suhu tubuh melalui evaporasi (Murniati, 2009). Family Menippidae memiliki komposisi jenis sebesar $1 \%$ untuk stasiun hutan mangrove. Kepiting jenis ini juga ditemui didaerah mangrove tetapi tidak sebanyak family ocypodidae, sesarmidae, dan grapsididae, karena keberadaannya didaerah mangrove hanya untuk 
mencari makan dan berlindung (Pratiwi and Rahmat, 2015).

\subsection{Kelimpahan Kepiting}

Jumlah dan total jenis kepiting pada stasiun hutan mangrove dan stasiun padang lamun dapat dilihat pada Tabel 4. Dari hasil pengamatan diperoleh kelimpahan kepiting pada stasiun hutan mangrove sebesar 411 individu/m² $\mathrm{m}^{2}$ sedangkan kelimpahan kepiting pada stasiun padang lamun sebesar 93 individu $/ \mathrm{m}^{2}$. Kelimpahan kepiting pada stasiun hutan mangrove lebih tinggi dari stasiun lamun, Hal ini terjadi karena beberapa faktor, salah satunya adalah letak stasiun hutan mangrove yang masih berada dekat sungai dan masih dipengaruhi oleh aliran sungai.

Muara sungai ini merupakan jalur keluar masuk kepiting untuk reproduksi. Kepiting betina yang akan bertelur, akan menuju ke arah laut dan kepiting muda yang dari laut kembali untuk menetap di mangrove melewati muara sungai (Prianto, 2007). Selain itu pada saat pasang juga digunakan kepiting untuk mencari makan (Christofoletti, 2013). Bahan organik yang terbawa arus sungai dapat mengendap pada muara sungai, sehingga menyediakan makanan bagi kepiting. Faktor lain diduga karena tersedianya persediaan makanan alami berupa serasah daun mangrove.

Keberadaan serasah mangrove menjadi pendukung ketersediaan nutrisi bagi kepiting, dan tersedianya vegetasi mangrove juga memiliki peran bagi kepiting, yaitu sebagai tempat habitat dan tempat perlindungan dari terpaan gelombang dan serangan predator, serta menjadi tempat bersembunyi bagi kepiting yang sedang melakukan perkawinan.

Dibandingkan dengan hasil pengamatan stasiun mangrove, stasiun padang lamun mempunyai kelimpahan yang lebih sedikit. Rendahnya kelimpahan kepiting pada stasiun padang lamun diduga karena pada stasiun padang lamun di Pantai Mertasari memiliki vegetasi padang lamun yang sedikit (Pratama, 2017), sehingga berpengaruh terhadap lingkungannya. Keberadaan ekosisitem lamun dan kerapatannya dapat mempengaruhi sebaran dan kelimpahan ikan dan krustasea yang berasosiasi dengan lamun, dan faktor-faktor yang mempengaruhi perubahan padang lamun (abiotic factor) menentukan terhadap sebaran biotanya (Kunsook et al., 2014; Ralph et al., 2013; Lee et al., 2012).
Faktor lain yang menyebabkan rendahnya kelimpahan kepiting pada staisun padang lamun disebabkan oleh serangan dari sesama kepiting dan ikan yang berasosiasi pada ekosistem padang lamun, serta kurangnya daerah untuk melindungi atau menyembunyikan diri dari ancaman predator pada stasiun padang lamun yang memiliki persen tutupan lamun yang sedikit. Selain itu terdapat ancaman dari kerusakan-kerusakan yang disebabkan oleh kondisi lingkungan seperti pasang surut (Pratiwi, 2010) yang mengakibatkan sedikitnya kelimpahan pada stasiun padang lamun.

Tabel 3

Jumlah dan total jenis kepiting pada stasiun pengamatan hutan mangrove dan padang lamun di pantai mertasari

\begin{tabular}{|c|c|c|c|c|}
\hline \multicolumn{3}{|c|}{ MANGROVE } & \multirow{2}{*}{$\begin{array}{l}\text { Jumlah } \\
\text { jenis }\end{array}$} & \multirow{2}{*}{ Total } \\
\hline $\mathrm{NO}$ & Famili & Nama Spesies & & \\
\hline 1 & \multirow{7}{*}{ Ocypodidae } & Uca perplexa & 501 & \multirow{7}{*}{1452} \\
\hline 2 & & Uca forcipata & 238 & \\
\hline 3 & & Uca rosea & 244 & \\
\hline 4 & & $\begin{array}{c}\text { Uca } \\
\text { dussumieri }\end{array}$ & 214 & \\
\hline 5 & & $\begin{array}{c}\text { Uca } \\
\text { triangularis }\end{array}$ & 154 & \\
\hline 6 & & Uca jocelynae & 88 & \\
\hline 7 & & $\begin{array}{l}\text { Ocypode } \\
\text { stimpsoni }\end{array}$ & 13 & \\
\hline 8 & Sesarmidae & $\begin{array}{l}\text { Parasesarma } \\
\text { rutilimanum }\end{array}$ & 151 & 151 \\
\hline 9 & Grapsidae & $\begin{array}{c}\text { Grapsus } \\
\text { albolineatus }\end{array}$ & 18 & 18 \\
\hline 10 & Portunidae & Scylla serrata & 15 & 15 \\
\hline 11 & Eriphiidae & $\begin{array}{l}\text { Myomenippe } \\
\text { fornasinii }\end{array}$ & 7 & 7 \\
\hline \multicolumn{3}{|c|}{ LAMUN } & \multirow[b]{2}{*}{$\begin{array}{l}\text { Jumlah } \\
\text { jenis }\end{array}$} & \multirow[b]{2}{*}{ Total } \\
\hline $\mathrm{NO}$ & Famili & Nama Spesies & & \\
\hline 1 & \multirow{4}{*}{ Diogenidae } & $\begin{array}{l}\text { Clibanarius } \\
\text { longitarsus }\end{array}$ & 86 & \multirow{4}{*}{330} \\
\hline 2 & & $\begin{array}{l}\text { Clibanarius } \\
\text { englaucus }\end{array}$ & 95 & \\
\hline 3 & & $\begin{array}{l}\text { Clibanarius } \\
\text { eurysternus }\end{array}$ & 70 & \\
\hline 4 & & $\begin{array}{l}\text { Clibanarius } \\
\text { striolatus }\end{array}$ & 79 & \\
\hline 5 & Eriphiidae & $\begin{array}{l}\text { Myomenippe } \\
\text { fornasinii }\end{array}$ & 7 & 7 \\
\hline 6 & Grapsidae & $\begin{array}{l}\text { Grapsus } \\
\text { albolineatus }\end{array}$ & 13 & 13 \\
\hline 7 & \multirow[b]{2}{*}{ Portunidae } & Scylla serrata & 11 & 11 \\
\hline 8 & & $\begin{array}{c}\text { Scylla } \\
\text { tanqueberra }\end{array}$ & 2 & 2 \\
\hline 9 & Matutidae & Matuta lunaris & 7 & 7 \\
\hline
\end{tabular}




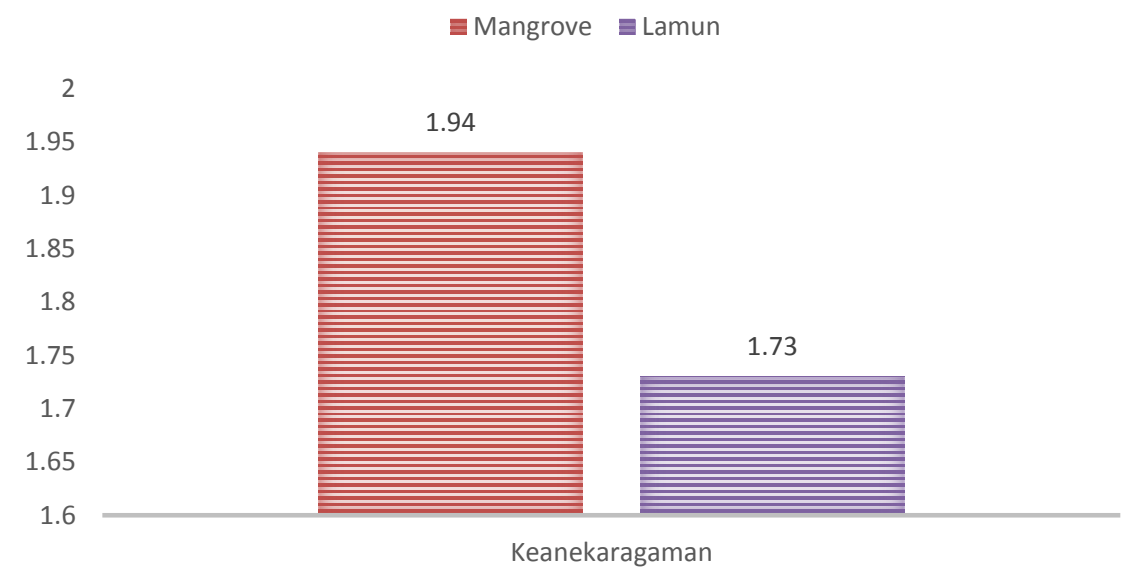

Gambar 3. Grafik Kesamaan Jenis Kepiting pada Stasiun Lamun dan Mangrove Pantai Mertasari

\subsection{Keanekaragaman Kepiting di Hutan Mangrove dan Padang Lamun}

Jumlah jenis dalam suatu komunitas disebut kekayaan jenis. Indeks keanekaragaman $\left(\mathrm{H}^{\prime}\right)$ dapat menunjukkan tingkat keanekaragaman jenis yang terdapat dalam suatu komunitas. Indek keanekaragaman jenis kepiting di Pantai Mertasari pada stasiun hutan mangrove diperoleh sebesar 1.94 dan pada stasiun padang lamun diperoleh sebesar 1.73 (Gambar 11). Kisaran nilai tersebut menggambarkan bahwa kekayaan jenis kepiting di Pantai Mertasari dapat dikategorikan memiliki keanekaragaman yang sedang mengindikasikan pada daerah tersebut mengalami produktivitas cukup, kondisi ekosistem cukup seimbang dan tekanan ekologis sedang.

Indeks keanekaragaman bervariasi disebabkan oleh beberapa faktor diantaranya ketidakseimbangan ekosistem yang disebabkan oleh tekanan lingkungan, artinya hanya jenis tertentu saja yang bertahan atau terdapatnya dominasi jenis pada daerah tersebut. Pada penelitian ini jumlah tiap spesies tidak sama dan tidak merata per stasiun, ada beberapa spesies yang jumlahnya ditemukan dalam jumlah yang besar sehingga menyebabkan keanekaragaman suatu ekosistem kecil. Suatu komunitas tidak akan memiliki nilai indek keanekaragaman yang tinggi apabila di dalam komunitas tersebut terdapat satu atau lebih jenis yang dominansinya mencolok jauh di atas sebagian besar jenis lainnya. Jumlah individu yang tidak merata setiap spesies berkaitan dengan pola adaptasi masing-masing spesies dan tersedianya habitat yang menunjang seperti pasang surut, makanan dan kondisi lingkungan (Pratiwi, 2010).

\section{Simpulan}

Kepiting yang ditemukan di ekosistem mangrove dan ekosistem lamun terdiri dari 7 famili dengan 20 spesies, 3 diantaranya ditemukan dapat hidup pada hutan mangrove dan padang lamun yakni Scylla serrata, Grapsus albolineatus dan Myomenippe fornasinii. Hal ini terjadi karena beberapa faktor, salah satunya pasang surut serta adanya aliran sungai yang menjadi media pemindahan habitat dari kepiting tersebut. Kelimpahan kepiting tertinggi terdapat pada stasiun mangrove sebesar 411 individu $/ \mathrm{m}^{2}$ sedangkan pada stasiun lamun sebesar 93 individu $/ \mathrm{m}^{2}$ yang disebabkan faktor seperti pasang surut, ketersediaan makanan dan factor lingkungan. Nilai Indeks Keanekaragaman $\left(\mathrm{H}^{\prime}\right)$ tertinggi pada stasiun mangrove sebesar 1.94 dan stasiun lamun sebesar 1.73 dengan kategori sedang mengindikasikan pada daerah tersebut mengalami produktivitas cukup, kondisi ekosistem cukup seimbang dan tekanan ekologis sedang.

\section{Saran}

Dengan mengacu pada hasil pengamatan dan pembahasan serta kesimpulan diatas maka disarankan melakukan penelitian lanjutan untuk menganalisis lebih dalam terkait struktur komunitas kepiting.

\section{Ucapan terimakasih}

Terima kasih disampaikan kepada seluruh pihak karena telah memberikan bimbingan dan saran dalam pembuatan jurnal ini. Terimakasih pada 
teman-teman yang telah ikut membantu di lapangan sehingga penelitian ini dapat berjalan dengan baik.

\section{Daftar Pustaka}

Christofoletti, R. A., Hattori, G. Y., \& Pinheiro, M. A. (2013). Food selection by a mangrove crab: temporal changes in fasted animals. Hydrobiologia, 702(1), 63-72.

Effendy, M. (2009). Pendekatan sistem dalam pemanfaatan sumberdaya dan pemanfaatan ruang pesisir dan lautan. Jurnal Kelautan: Indonesian Journal of Marine Science and Technology, 2(2), 141-149.

Epifanio, C. E. (2013). Invasion biology of the Asian shore crab Hemigrapsus sanguineus: a review. Journal of Experimental Marine Biology and Ecology, 441, 33-49.

Hamidy, R. (2010). Struktur Keragaman Komunitas Kepiting di Kawasan Hutan Mangrove Fakultas Kelautan, Universitas Riau, Desa Purnama Dumai. Ilmu Lingkungan, 4(2), 81-91.

Krebs, C. J., O’Donoghue, M., Taylor, S., Kenney, A. J., Hofer, E. J., \& Boutin, S. (2016). Predicting white spruce cone crops in the boreal forests of southern and central Yukon. Canadian Journal of Forest Research, 47(1), 47-52.

Kunsook, C., Gajaseni, N., \& Paphavasit, N. (2014). The feeding ecology of the blue swimming crab, Portunus pelagicus (Linnaeus, 1758), at Kung Krabaen Bay, Chanthaburi Province, Thailand. Tropical life sciences research, 25(1), 13-27.

Lee, Q., Yaakub, S. M., Ng, N. K., Erftemeijer, P. L. A., \& Todd, P. A. (2012). The crab fauna of three seagrass meadows in Singapore: a pilot study. Nature in Singapore, 5, 363-368.

Moody, R. M., \& Aronson, R. B. (2012). Predatorinduced defenses in a salt-marsh gastropod. Journal of Experimental Marine Biology and Ecology, 413, 78-86.

Murniati, D. C. (2009). Perbandingan Luas Tutupan Spoon Toped Setae Maksiliped Kedua Pada Uca spp, (Brachyura: Ocypodidae). Zoo Indonesia, 18(1), 1-8.

Negri, M., Pileggi, L. G., \& Mantelatto, F. L. (2012). Molecular barcode and morphological analyses reveal the taxonomic and biogeographical status of the striped-legged hermit crab species Clibanarius sclopetarius (Herbst, 1796) and Clibanarius vittatus (Bosc, 1802)(Decapoda: Diogenidae). Invertebrate Systematics, 26(6), 561-571.
Ng, P. K., Guinot, D., \& Davie, P. J. (2008). Systema Brachyurorum: Part I. An annotated checklist of extant brachyuran crabs of the world. The Raffles Bulletin of Zoology, 17(1), 1-286.

Harahap, E., Aziza, N., \& Affandi, A. (2014). Menentukan Tekstur Tanah Dengan Metode Perasaan Di Lahan Politani. Jurnal Nasional Ecopedon, 2(2), 13-15.

Pratama, P. S., Wiyanto, D. B., \& Faiqoh, E. (2017). Struktur Komunitas Perifiton Pada Lamun Jenis Thalassia hemprichii dan Cymodocea rotundatta di Kawasan Pantai Sanur. Journal of Marine and Aquatic Sciences, 3(1), 123-133.

Pratiwi, R. (2010). Komposisi keberadaan krustasea di mangrove delta Mahakam Kalimantan Timur. Makara Journal of Science, 13(1), 65-76.

Pratiwi, R., \& Rahmat, R. (2015). Sebaran kepiting mangrove (crustacea: decapoda) yang terdaftar di koleksi rujukan pusat penelitian oseanografi-lipi 1960-1970. Berita Biologi, 14(2), 195-202.

Pratiwi, R., \& Widyastuti, E. (2014). Pola sebaran dan zonasi krustasea di hutan bakau perairan Teluk Lampung. Zoo Indonesia, 22(1), 11-21.

Prianto, E. (2007). Peran Kepiting sebagai Spesies Kunci (Keystone Spesies) pada Ekosistem Mangrove. In Prosiding Forum Perairan Umum Indonesia IV. Balai Riset Perikanan Perairan Umum, Banyuasin. Palembang, Indonesia, 30 November 2007 (pp. 89-99).

Ralph, G. M., Seitz, R. D., Orth, R. J., Knick, K. E., \& Lipcius, R. N. (2013). Broad-scale association between seagrass cover and juvenile blue crab density in Chesapeake Bay. Marine Ecology Progress Series, 488, 51-63.

Suprayogi, D., Siburian, J., \& Hamidah, A. (2014). Keanekaragaman Kepiting Biola (Uca spp.) di Desa Tungkal I Tanjung Jabung Barat. Biospecies, 7(1), 22-28.

Toscano, B. J., \& Griffen, B. D. (2012). Predatory crab size diversity and bivalve consumption in oyster reefs. Marine Ecology Progress Series, 445, 65-74.

White, S. M., \& Madsen, E. A. (2016). Tracking tidal inundation in a coastal salt marsh with Helikite airphotos: Influence of hydrology on ecological zonation at Crab Haul Creek, South Carolina. Remote Sensing of Environment, 184, 605-614.

Zulkifli, H., \& Setiawan, D. (2011). Struktur komunitas makrozoobentos di perairan sungai musi kawasan Pulokerto sebagai instrumen biomonitoring. Jurnal Natur Indonesia, 14(1), 95-99.

(c) 2017 by the authors; licensee Udayana University, Indonesia. This article is an open access article distributed under the terms and conditions of the Creative Commons Attribution license (http://creativecommons.org/licenses/by/3.0/). 